University of Nebraska - Lincoln

DigitalCommons@University of Nebraska - Lincoln

2013

Review and reinterpretation of Rio Grande silvery minnow reproductive ecology using egg biology, life history, hydrology, and geomorphology information

\author{
Carl Nicolas Medley \\ National Park Service \\ Patrick D. Shirey \\ University of Notre Dame
}

Follow this and additional works at: http://digitalcommons.unl.edu/natlpark

Medley, Carl Nicolas and Shirey, Patrick D., "Review and reinterpretation of Rio Grande silvery minnow reproductive ecology using egg biology, life history, hydrology, and geomorphology information" (2013). U.S. National Park Service Publications and Papers. 133. http://digitalcommons.unl.edu/natlpark/133

This Article is brought to you for free and open access by the National Park Service at DigitalCommons@University of Nebraska - Lincoln. It has been accepted for inclusion in U.S. National Park Service Publications and Papers by an authorized administrator of DigitalCommons@University of Nebraska - Lincoln. 


\title{
Review and reinterpretation of Rio Grande silvery minnow reproductive ecology using egg biology, life history, hydrology, and geomorphology information
}

\author{
Carl Nicolas Medley ${ }^{1 *}$ and Patrick D. Shirey ${ }^{2}$ \\ ${ }^{1}$ Water Resources Division, National Park Service, Fort Collins, CO 80525, USA \\ ${ }^{2}$ Department of Biological Sciences, University of Notre Dame, Notre Dame, IN 46556, USA
}

\begin{abstract}
To inform management actions to recover the endangered Rio Grande silvery minnow (Hybognathus amarus, RGSM), we (1) calculated the terminal settling velocities of newly expelled and water-hardened RGSM eggs for the observed range of suspended sediment concentrations and water temperatures in the Rio Grande, New Mexico, USA, and (2) reviewed RGSM reproductive ecology in the context of egg biology, the species' life history, and the historic and contemporary hydrology and geomorphology of the Rio Grande. Results show that in a naturally functioning riverine environment, the location and timing of spawning, the ontogenic stage of egg development, and habitat-specific differences in sediment and temperature that influence egg-settling rates interact to (1) prevent egg suffocation, (2) promote egg entrainment in clear, warm, productive floodplain habitats, and (3) limit downstream population displacement. Our research suggests that the RGSM is primarily a demersal, floodplain spawning species that evolved eggs that are secondarily buoyant in high-sediment environments rather than a main channel, pelagic broadcast-spawning species with an evolved long-distance, downstream drift phase, as previously reported. The current high magnitude of egg drift is hypothesized to be an artefact of contemporary river management and channelization, leading to reduced lateral connectivity, floodplain abandonment, and habitat degradation. Conservation actions implemented to restore historic channel form and reconnect low-velocity backwater and floodplain habitats are recommended. In the absence of a documented upstream migration of adult fish, removal of barriers to a presumed upstream movement is unlikely to provide immediate benefits to RGSM. Copyright (C) 2013 John Wiley \& Sons, Ltd.
\end{abstract}

KEY WORDS Rio Grande silvery minnow; reproductive ecology; life history; egg; demersal; pelagic; hydrology; geomorphology

Received 7 August 2012; Revised 11 January 2013; Accepted 11 January 2013

\section{INTRODUCTION}

In lowland floodplain rivers of western North America, a reproductive guild of small, broadcast-spawning minnow (BSM) species has evolved in hydrologically variable but seasonably predictable rivers. These minnows maximize their reproductive success by spawning in response to rapidly increasing flows associated with spring runoff and summer rainstorms (Platania and Altenbach, 1998). Members of this guild have declined dramatically as a result of a multitude of negative impacts (Bestgen and Platania, 1991; Platania, 1991) primarily driven by dam construction and water resource development and the attendant effects on hydrology, geomorphology, and river habitats (Lagasse, 1981; Ward and Stanford, 1995; Collier et al., 1996; Dean and Schmidt, 2011; Swanson et al., 2011). Many now occupy a small proportion of their former range, are listed as threatened and endangered under state laws and the federal Endangered Species Act, or extinct (Deacon et al., 1979; Miller et al., 1989; Williams et al., 1989; Haslouer et al., 2005). Accordingly, these species are the focus of intensive efforts to resolve the

*Correspondence to: Carl Nicolas Medley, Water Resources Division, National Park Service, Fort Collins, CO 80525, USA.

E-mail: carl_medley@nps.gov conflicts between water resource management and species conservation (Edwards and Contreras-Balderas, 1991; Ward and Booker, 2003; Cowley, 2006; Ward and Booker, 2006; Ward and Pulido-Velázquez, 2008), including research efforts to better understand the management actions that will promote their recovery (Medley, 2009).

The reproductive strategies and egg types of seven Rio Grande Basin BSM species have been characterized (Platania and Altenbach, 1998). Six, including the federally endangered Rio Grande silvery minnow (Hybognathus amarus, RGSM; Figure 1), were reported to be 'pelagic broadcast spawners', fish that broadcast non-adhesive, semi-buoyant eggs (Figure 2) into the water column, which then drift downstream. The physical properties of RGSM eggs and the ontogenic phases of egg development have also been characterized (Platania and Altenbach, 1998; Cowley et al., 2005, 2009). Furthermore, a considerable amount of published and unpublished information exists documenting RGSM spatial and temporal population trends, spawning periodicity, egg drift, and RGSM movement, and represents the most complete description concerning the reproductive ecology of any BSM. Consequently, the RGSM information, when considered with information about other BSM, perhaps provides the best model species to understand the general spawning ecology of this group of BSM species. 


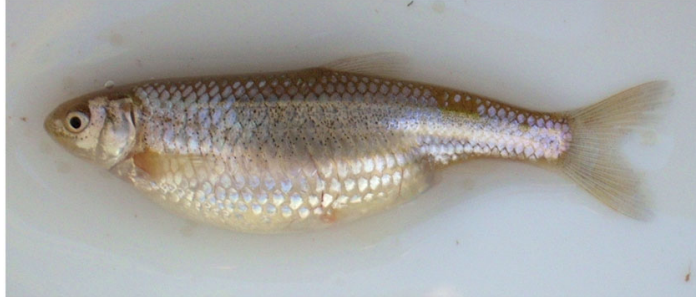

Figure 1. Rio Grande silvery minnow; gravid female.

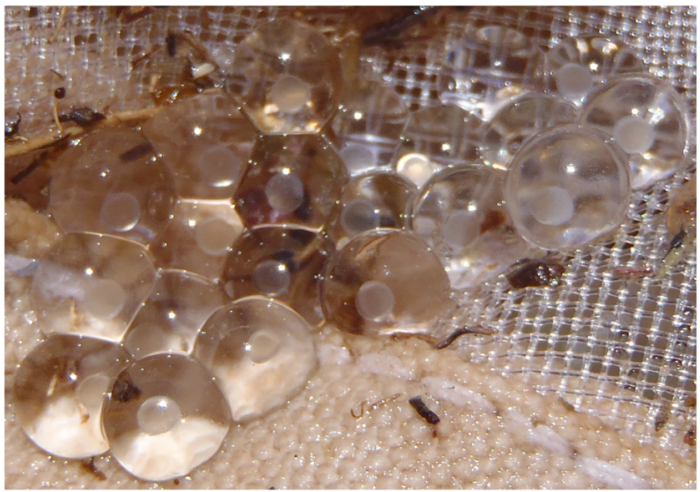

Figure 2. Water-hardened Rio Grande silvery minnow eggs.

The RGSM is a small BSM ( $<100 \mathrm{~mm})$ native to the Rio Grande basin, including the Pecos River, with an original distribution from north central New Mexico (Cope and Yarrow, 1875) to the river's mouth in Brownsville, Texas (Girard, 1856). Currently, the species' known distribution is restricted to two river reaches amounting to less than $10 \%$ of its historic range. The extant range includes the remaining native population downstream of Angostura Dam near Albuquerque to Elephant Butte Reservoir in New Mexico (Bestgen and Platania, 1991) and a recently introduced experimental population in Big Bend National Park, Texas (U.S. Fish and Wildlife Service, 2008; Shirey and Lamberti, 2010).

\section{EGG BIOLOGY AND LIFE HISTORY}

RGSM spawn in late April and May during flood pulses or managed Cochiti Reservoir releases associated with spring snowmelt, when water temperatures exceed $18^{\circ} \mathrm{C}$ (Sublette et al., 1990; Platania and Altenbach, 1998; Propst, 1999; Platania and Dudley, 2005). After expulsion and fertilization, eggs may settle or drift suspended by turbulent flows. Newly expelled eggs are spherical and $\sim 1.0 \mathrm{~mm}$ in diameter (Platania and Altenbach, 1998). Eggs rapidly water harden and swell to greater than 50 times their initial volume, becoming $\sim 3.75 \mathrm{~mm}$ in diameter (Figure 2) with a density of $1.00281 \mathrm{~g} \mathrm{~cm}^{-3}$ after $1 \mathrm{~h}$ (Cowley et al., 2005, 2009). Eggs have been observed drifting until they are entrained in low-velocity habitats (backwaters, channel edges, and floodplains) or hatch 24-72 h post-fertilization. Newly hatched larvae have also been reported to drift passively for another 3 days until their air bladders develop whereupon they are thought to actively seek low-velocity habitats (Platania and Altenbach, 1998).

Moore (1944) hypothesized that egg suspension and downstream drift during high flows evolved because it confers a reproductive advantage over substrate spawning by reducing egg suffocation (Johnston and Page, 1992). Consequently, RGSM and other BSM are hypothesized to be main channel, pelagic broadcast-spawning fish with an evolved long-distance downstream egg and larval drift phase as a core component of their life history strategy. In highly regulated and modified rivers with reduced floodplain connection, eggs have been observed to drift long distances downstream $(>150 \mathrm{~km})$ leading to speculation that RGSM and other BSM must undertake an upstream migration during their lifetime to counter the effects of downstream drift (Platania, 1995; Bestgen et al., 2010). However, these presumed minnow migrations remain undocumented (Luttrell et al., 1999; Medley et al., 2007; PBS\&J, 2011). Moore's hypothesis has led to the supposition that populations of BSM have declined because of dam construction and river fragmentation, which creates river reaches too short to accommodate the life history of these fish (Platania and Altenbach, 1998; Luttrell et al., 1999; Dudley and Platania, 2007; Perkin and Gido, 2011; Archdeacon and Remshardt, 2012). Accordingly, the removal of irrigation diversions and other barriers to upstream movement or migration, or the construction of fish passageways to re-establish longitudinal connectivity, has been recommended as the primary conservation need for RGSM and other threatened BSM populations (Dudley and Platania, 2007; Perkin and Gido, 2011).

However, BSM populations still persist in fragmented and highly modified river reaches. Alternatively, other studies have concluded that BSM species that spawn on the rising limb of a flood hydrograph take advantage of egg retention mechanisms associated with channel storage and flood attenuation that promotes entrainment and settling of drifting eggs in areas of low-velocity flow near spawning sites (Fluder et al., 2007; Medley et al., 2007; Medley, 2009; Medley et al., 2009; Widmer et al., 2012). These species may further enhance egg retention by spawning in remnant low-velocity river channels or inundated floodplain habitats (Gonzales et al., 2012) when available. Efficient egg retention limits downstream displacement of BSM populations and perhaps increases reproductive success by avoiding the need for energetically expensive upstream migrations (Hirshfield and Tinkle, 1975; Speirs and Gurney, 2001; Medley et al., 2007). This hypothesis proposes that the contemporary high magnitude of downstream egg drift is an artefact of the geomorphic and habitat changes that accompany dam construction and flow regulation and the subsequent reduction in lowvelocity river and floodplain habitats; short reaches of river that retain remnants of functional habitat features may still promote efficient egg retention sufficient to support healthy BSM populations (Medley et al., 2007; Widmer et al., 2012). Consistent with this hypothesis, conservation 
actions that help restore the geomorphic functions and processes that create and maintain the natural channel form and re-establish lateral floodplain connectivity are considered the primary conservation need (Medley, 2009; Magana, 2012).

The interpretation of recent observations regarding RGSM and BSM spawning behaviour is confounded because the habitat in the contemporary Rio Grande and other large floodplain rivers has been severely altered (Benke, 1990; Crawford et al., 1993; Scurlock, 1998; Dean and Schmidt, 2011). Life history strategies of BSM that either prevent downstream population displacement or subsequently compensate for downstream egg drift may operate synergistically. However, in the highly modified contemporary Rio Grande, the relative contribution of each strategy and the ultimate cause of the current imbalance between the observed magnitude of egg and larval drift and upstream fish movement or migration remains unresolved. The consequences of getting the science wrong may be costly in both money and loss of support for endangered species research and recovery. With tight government budgets and difficult choices on the number and scope of management actions that can be funded, scientists must identify the correct cause and effect relationships using the best available science and implement appropriate conservation measures to effectively recover species. A more complete understanding of BSM egg biology and BSM life history strategies is needed to better inform such management decisions.

Eggs of BSM settle in non-turbulent water (Platania and Altenbach, 1998; Cowley et al., 2005, 2009). The rate at which a spherical minnow egg settles (or rises) in a still medium is dependent on the size and density of the sphere, the density and viscosity of the medium (the latter being temperature dependent), and how these variables affect the relative magnitude of the three forces acting on the egg in suspension; gravity, buoyancy, and drag (friction). The magnitude of the downward force is a consequence of gravity acting on the mass of the egg. The magnitude of the upward acting force of buoyancy is dependent upon the mass of the fluid medium displaced by the egg. Settling occurs when the downward force of gravity acting on an egg exceeds the upward force of buoyancy. The terminal settling velocity is reached when the drag force exactly opposes the net downward force acting on the egg. When the density of the medium is greater than the density of the egg, the sphere will rise and float. The terminal settling velocity of silvery minnow eggs is therefore dependent upon the size and density of the egg and the temperature and sediment concentration of river water.

Recent observations that RGSM utilize and likely spawn in seasonally flooded habitats connected to the main channel (SWCA Environmental Consulting, 2008, 2009, 2010, 2010, 2011; Gonzales et al., 2012) suggest that their eggs may be subjected to a wide variation of temperatures and suspended sediment concentrations known to exist within these environments. Egg settling rate varies as a function of temperature, sediment concentration, and the ontogenic stage of egg development (Cowley et al., 2009). The hydrobiology of the RGSM egg suggests a complex but predictable relationship between egg properties, the physical properties of water, and the abundance and availability of different aquatic habitat types that create spatiotemporal variability in suspended sediment concentrations and temperatures in the floodplain and main channel. It is hypothesized that this environmental variability can influence the rate and magnitude of egg settling and retention. Understanding the biology of silvery minnow eggs may provide insight into RGSM and BSM adaptations to the heterogeneous environment of the historic Rio Grande. The magnitude of historic habitat alterations (Mussetter Engineering, Inc, 2002) also suggests that the contemporary state of the Rio Grande is a poor model for understanding the evolutionary pressures that have driven RGSM life history. Therefore, a review of the species' reproductive ecology in context with the historic geomorphology of the Rio Grande is necessary to inform effective management actions to recover the endangered RGSM.

We use available data to calculate the terminal settling velocity of newly expelled and water-hardened RGSM eggs in habitats with no flow velocity for a range of sediment and temperature conditions observed in the Rio Grande. Differences in egg-settling velocity may have important ecological consequences on egg drift and retention, egg survival and hatching, and young-of-year survival and recruitment. These results are used to explore the possible interactions between egg-settling velocity, egg properties, sediment concentrations, temperatures, and habitat availability. We then reinterpret the RGSM reproductive ecology on the basis of egg biology, historic Rio Grande geomorphology, RGSM life history, and recent observations suggesting that demersal spawning in lowvelocity main channel and floodplain habitats is consistent with what is known about the reproductive ecology of other species of Hybognathus and other BSM.

\section{CALCULATION OF EGG-SETTLING VELOCITY}

Terminal settling velocities of newly expelled and waterhardened RGSM eggs were calculated at suspended sediment concentrations and water temperatures observed in the main channel and floodplain of the Rio Grande using Stokes' law:

$$
v_{\mathrm{t}}=\sqrt{\frac{\left(\rho_{\mathrm{s}}-\rho_{\mathrm{f}}\right)}{\rho_{\mathrm{f}}} \frac{g}{C_{\mathrm{D}} / 2} \frac{V}{A}}
$$

where $v_{\mathrm{t}}$ is the terminal settling velocity $\left(\mathrm{cm} \mathrm{s}^{-1}\right), \rho_{\mathrm{s}}$ the density of the sphere $\left(\mathrm{g} \mathrm{cm}^{-3}\right), \rho_{\mathrm{f}}$ the density of medium $\left(\mathrm{g} \mathrm{cm}^{-3}\right), g$ the acceleration due to gravity $\left(\mathrm{cm} \mathrm{s}^{-2}\right), C_{\mathrm{D}}$ the drag coefficient, $V$ the volume of sphere $\left[4 / 3 \pi \mathrm{r}^{3}\left(\mathrm{~cm}^{3}\right)\right]$, and $A$ the cross-sectional area of the sphere $\left[\pi \mathrm{r}^{2}\left(\mathrm{~cm}^{2}\right)\right]$.

For large particles, drag is a function of the settling velocity. Because settling velocity and drag are interdependent, there is no easy analytical solution to determine settling velocity of a large sphere. The standard iterative approach 
was used to calculate egg-settling rates for newly expressed and water-hardened eggs at suspended sediment concentrations $\left(0-150000 \mathrm{mgl}^{-1}\right)$ and temperatures $\left(18\right.$ and $30^{\circ} \mathrm{C}$; reflecting silvery minnow minimum spawning temperatures and near maximum floodplain temperatures, respectively), observed in the Rio Grande (SWCA Environmental Consulting, 2009). At expulsion, RGSM eggs are spherical and $\sim 1.0 \mathrm{~mm}$ in diameter (Platania and Altenbach, 1998). Water-hardened eggs are $\sim 3.75 \mathrm{~mm}$ in diameter with a density of $1.00281 \mathrm{~g} \mathrm{~cm}^{-3}$ (Cowley et al., 2005, 2009). The density of newly expelled eggs has not been determined but was backcalculated as $1.14818 \mathrm{~g} \mathrm{~cm}^{-3}$ using the reported properties of water-hardened eggs (Cowley et al., 2009), assuming that egg swelling is dependent only on the passive movement of water through a semi-permeable membrane in response to an osmotic gradient.

The simplified form of Equation (1) for small particles was used to make an initial estimate of the terminal eggsettling velocity:

$$
v_{\mathrm{t}}=\frac{g D^{2}}{18 \mu}\left(\rho_{\mathrm{s}}-\rho_{\mathrm{f}}\right)
$$

where $\mu$ is the dynamic viscosity $\left(\mathrm{g} \mathrm{cm}^{-1} \cdot \mathrm{s}^{-1}\right)$ and $D$ the particle diameter $(\mathrm{cm})$.

This initial estimate of $v_{\mathrm{t}}$ was used to derive an estimated Reynolds number $(R e)$ for a settling egg:

$$
R e=\frac{v_{\mathrm{t}} \rho_{\mathrm{f}} D}{\mu}
$$

The Reynolds number was then used to estimate a drag coefficient using the general equation of Cheng (2009):

$$
C_{\mathrm{D}}=\frac{24}{R e}(1+0.27 R e)^{0.43}+0.47\left[1-\exp \left(-0.04 R e^{0.38}\right)\right]
$$

The drag coefficient estimate was used to calculate settling velocity using Equation (1). The new estimate of settling velocity $\left(v_{t}\right)$ was used to recalculate the estimated Reynolds number and the calculation process repeated until terminal settling velocity converged to a constant. Water viscosity for the calculations was assumed to be dependent only on temperature and unaffected by interactions with suspended sediment at the concentrations considered (Woo et al., 1988).

\section{EGG SETTLING RATES}

Newly expelled RGSM eggs were calculated to settle in clear (sediment concentration of $0.0 \mathrm{mg} \mathrm{l}^{-1}$ ), non-turbulent water at 2.95 and $3.32 \mathrm{~cm} \mathrm{~s}^{-1}$ in 18 and $30^{\circ} \mathrm{C}$ water, respectively (Figure 3 ). Settling velocities of larger, less dense water-hardened eggs decrease to 0.79 and $0.87 \mathrm{~cm} \mathrm{~s}^{-1}$ at 18 and $30^{\circ} \mathrm{C}$, respectively (Figure 4). Settling velocities decrease to zero as sediment concentrations increase to the point at which egg density equals the density of the water sediment mixture. Newly expelled RGSM eggs become

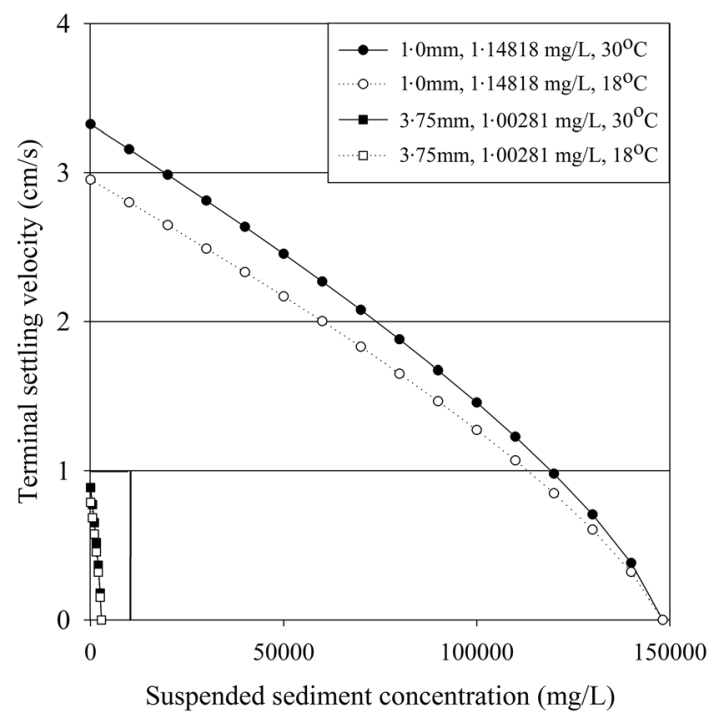

Figure 3. Relationships between terminal settling velocity $\left(\mathrm{cm} \mathrm{s}^{-1}\right)$, sediment concentration $\left(\mathrm{mg} \mathrm{l}^{-1}\right)$, and water temperature $\left({ }^{\circ} \mathrm{C}\right)$ for newly expelled RGSM eggs (egg diameter $=1.00 \mathrm{~mm}$, density $=1.14818 \mathrm{~g} \mathrm{~cm}^{-3}$ ).

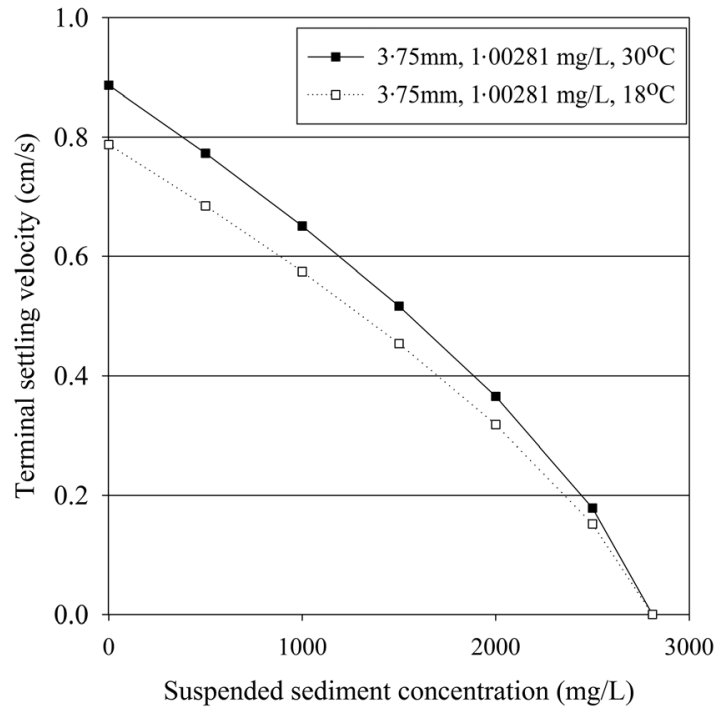

Figure 4. Relationships between terminal settling velocity $\left(\mathrm{cm} \mathrm{s}^{-1}\right)$, sediment concentration $\left(\mathrm{mg} \mathrm{l}^{-1}\right)$, and water temperature $\left({ }^{\circ} \mathrm{C}\right)$ for waterhardened (more than $1 \mathrm{~h}$ old) RGSM eggs (egg diameter $=3.75 \mathrm{~mm}$, density $\left.=1 \cdot 00281 \mathrm{~g} \mathrm{~cm}^{-3}\right)$.

positively buoyant and float (calculated negative settling velocity) when sediment concentrations exceed egg density (>148 $180 \mathrm{mg} \mathrm{l}^{-1}$ ), whereas water-hardened eggs float at sediment concentrations greater than $2810 \mathrm{mg} \mathrm{l}^{-1}$. For a specific egg size and density, eggs will settle faster in clear versus sediment-laden water and faster in warm versus cold water.

The results support the general conclusions of other authors that both newly expelled and water-hardened RGSM eggs will settle in non-turbulent water except in high concentrations of suspended sediment (Platania and Altenbach, 1998; Cowley et al., 2009). Our calculations show that recently spawned, small, dense RGSM eggs can settle out quickly in warm, low-velocity habitats with little suspended sediment. Results also confirm that 
water-hardened eggs will sink slowly in low sediment environments but are easily suspended and become positively buoyant in high concentrations of suspended sediment observed in the Rio Grande (Cowley et al., 2009).

Results suggest that egg-settling rates may be highly variable in a natural river environment with high spatial variability in sediment and temperature. During the high spring flows when RGSM spawn, suspended sediment concentrations in the main channel increase orders of magnitude over those observed at base flow as fine sediments from tributaries and the channel bed are mobilized (Graf, 1971). A small dataset documents the range of suspended sediment concentrations in the Rio Grande near Bernardo [U.S. Geological Survey (USGS) Gage 08332000] prior to the closure of Cochiti Dam (Figure 5). Suspended sediment concentrations during high spring flows in May and June when RGSM spawn exceeded that necessary to float a water-hardened $\left(2810 \mathrm{mgl}^{-1}\right)$ egg $59.0 \%$ of the time, but newly expelled eggs sank at all but the single maximum sediment concentration (167000 $\mathrm{mg}^{-1}$ ) observed during the spawning season, for the period of record. No data are available documenting the spatial variability of floodplain sediment concentrations in the contemporary Rio Grande, although water clarity within the floodplain, especially at the floodplain margins and in areas of low velocity, is often much clearer than water clarity in or near the main channel (authors' personal observation). A recent dataset shows that water temperatures vary widely in the contemporary Rio Grande and temperatures in floodplain margins and pond habitats may exceed $30^{\circ} \mathrm{C}$ (SWCA Environmental Consulting, 2009). During snowmelt runoff in the Rio Grande, water temperatures in the mainstem stay relatively cool.

Water-hardened RGSM eggs are buoyant in high-sediment environments. Therefore, it is unlikely that they can be suffocated by sediment as previously reported (Moore, 1944; Platania and Altenbach, 1998). As fine sediments settle, a density gradient is created above the riverbed. An egg will be suspended in the water column at the point where the fluid density equals that of the $\mathrm{egg}\left(1.00281 \mathrm{~g} \mathrm{~cm}^{-3}\right)$. As sediments continue to settle, the density gradient of the water sediment mixture above the bed surface increases, but the egg will remain at its equilibrium point slightly above the bed surface. Consequently, fine sediments are unlikely to bury water-hardened eggs, contrary to previous reports. If, after initial entrainment the sediment concentration should increase, the egg will rise and potentially drift until again settling in a warm, low-sediment environment.

\section{HABITAT HETEROGENEITY IN THE HISTORICAL RIO GRANDE}

Historically, the river was wide and shallow (Figure 6), with a braided channel (Figure 7) and an extensive, lowelevation floodplain (2-4 km wide) (Crawford et al., 1993; Molles et al., 1998; Scurlock, 1998; Dean and Schmidt, 2011). In all but the driest years the river was seasonally

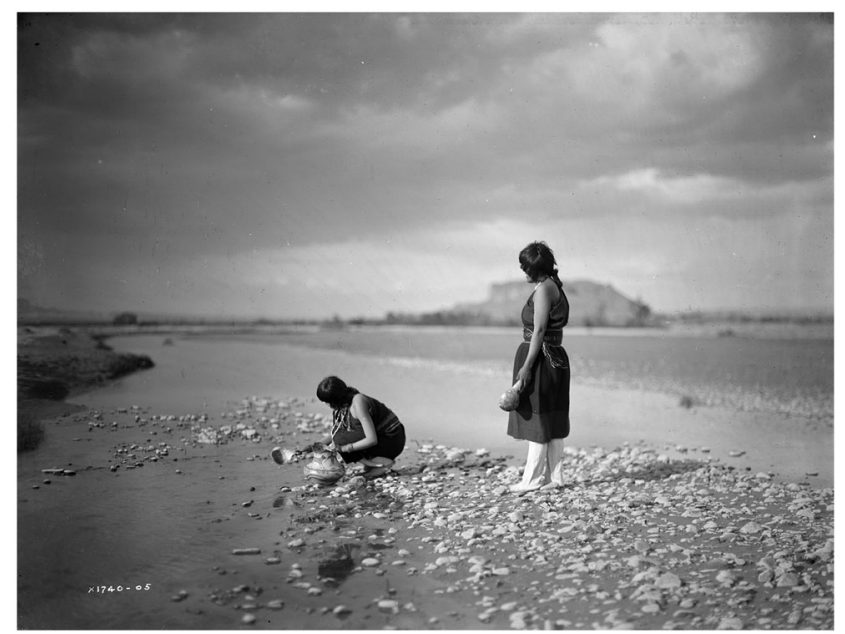

Figure 6. 'On the Rio Grande' near San Ildefonso, NM, 1905, showing a wide, braided, and shallow river. Edward S. Curtis. Courtesy Palace of the Governors Photo Archives (NMHM/DCA), 143730.

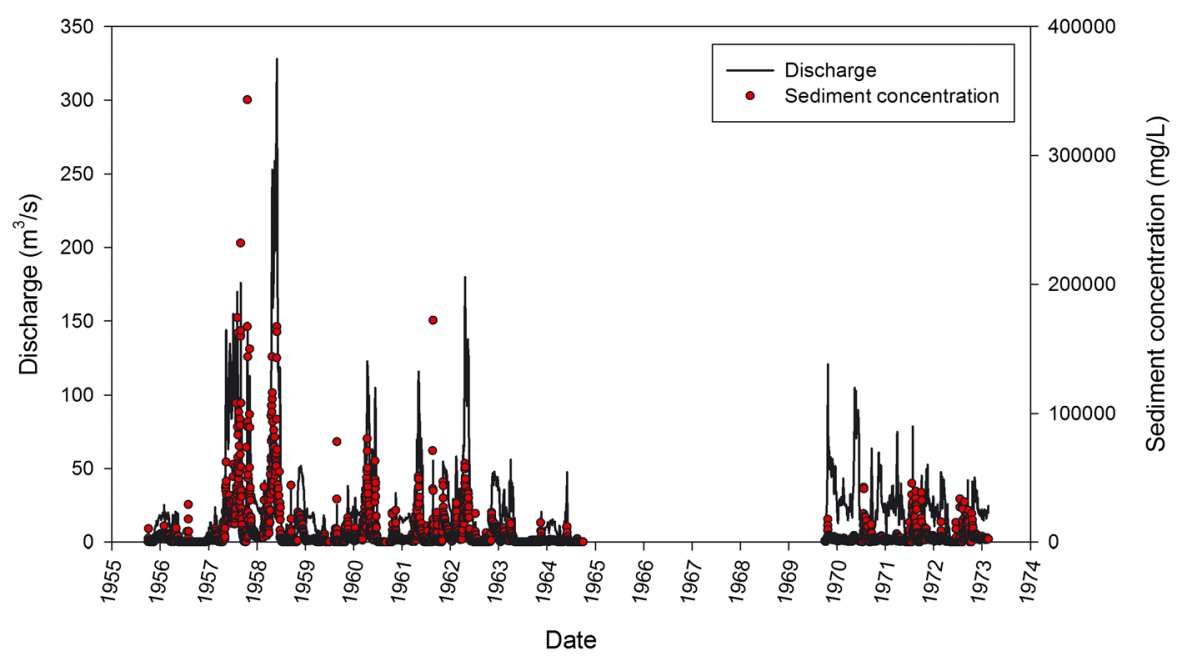

Figure 5. Discharge and suspended sediment concentrations at Rio Grande near Bernardo, NM (USGS Gage 08332000) prior to the closure of Cochiti Reservoir (1975). 


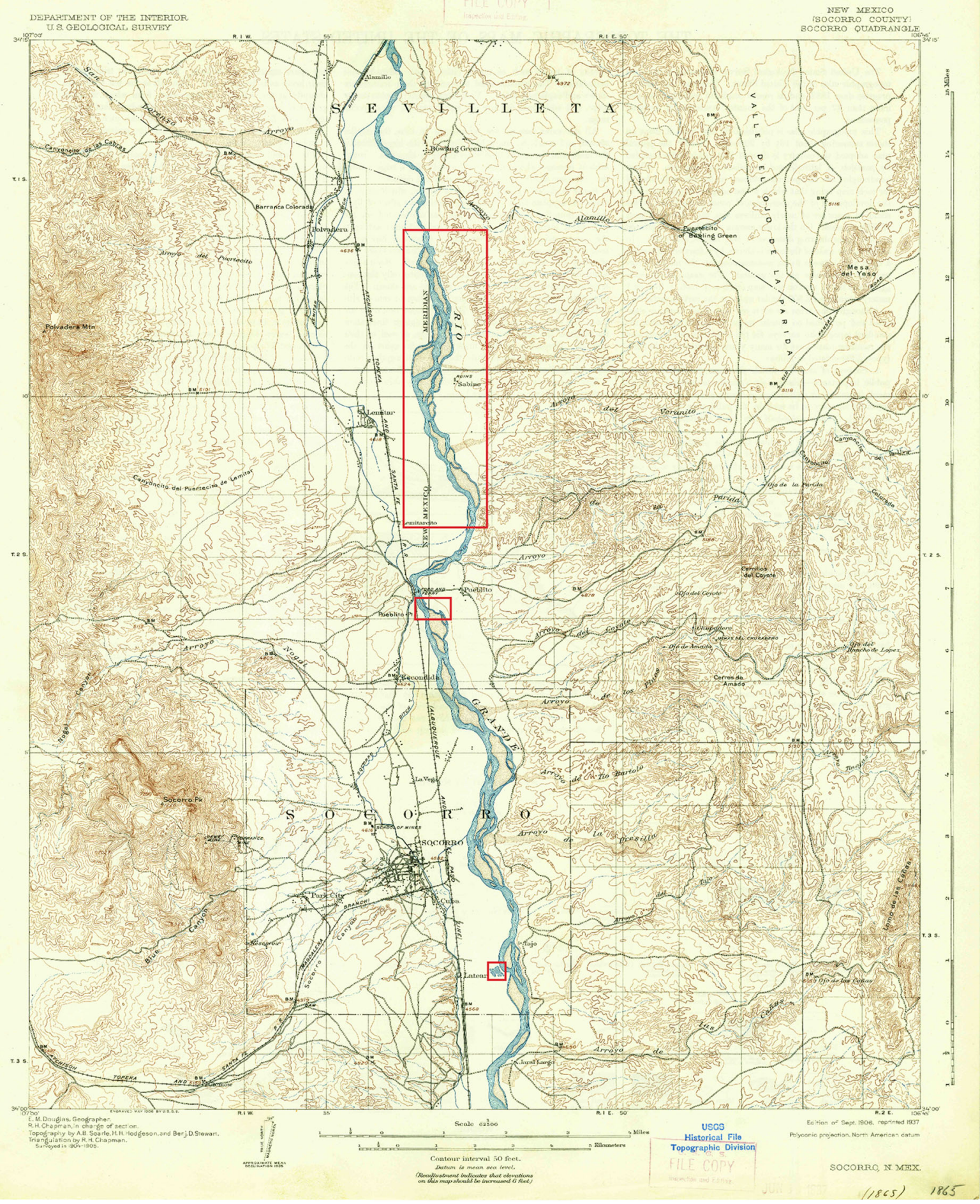

Figure 7. U.S. Geological Survey map of the Rio Grande near Socorro, NM, 1906, showing a wide braided channel that wandered within an extensive, connected floodplain. Habitat features highlighted from north to south include a braided river channel, a cutoff, and a floodplain lake.

connected to its floodplain which provided extensive low-velocity habitat for spawning fish and developing eggs and larvae (Figure 8). However, flow regulation, channel training and modification, removal of woody debris, sediment management, levee construction, lateral confinement and encroachment of non-native vegetation have changed the geomorphology of the Rio Grande (Lagasse, 1981; Sparks, 1995; Mussetter Engineering, Inc, 2002; Porter and Massong, 2004; Dean and Schmidt,
2011). The Rio Grande narrowed considerably between 1918 and 1962 as the river shifted from historical braided conditions to a narrow and deep channel disconnected from the floodplain (Swanson et al., 2011) (Figures 9-11). This greatly decreased the availability and diversity of habitat types.

To establish that environmental heterogeneity is a potential selective pressure in the evolution of RGSM reproductive ecology we should provide evidence that 


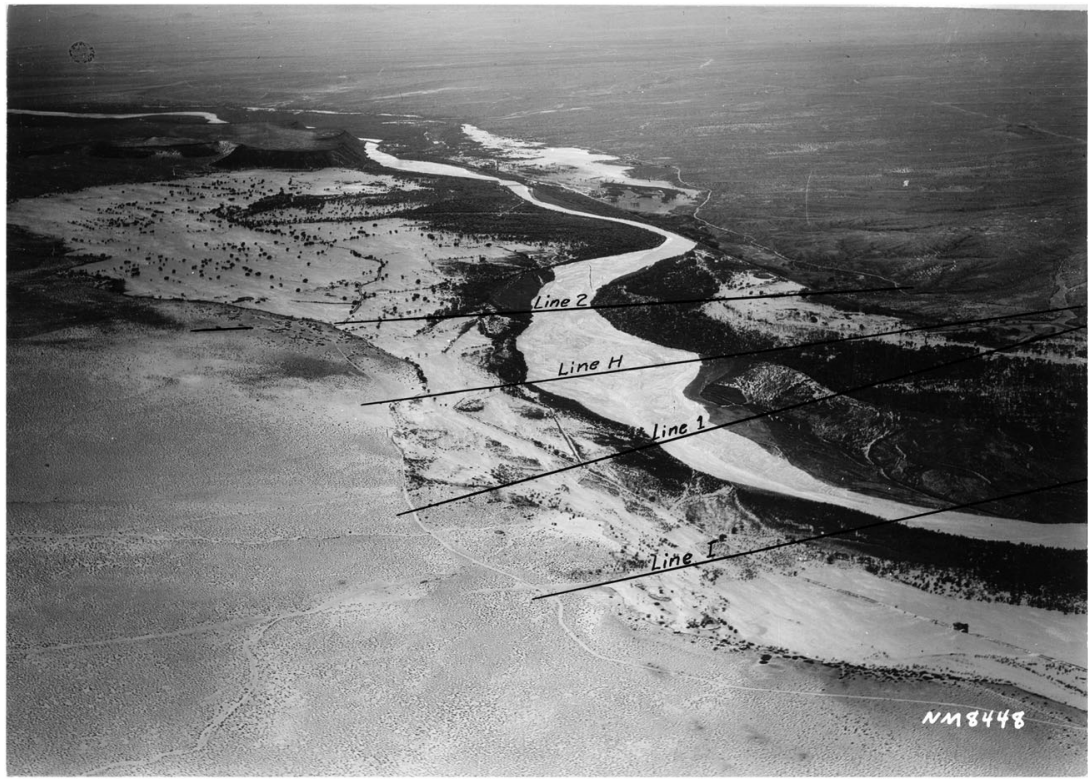

Figure 8. Aerial photograph looking southwest showing braided channel and broad, inundated floodplain with lake-like conditions along Rio Grande near San Marcial, NM, 27 May 1937. E. D. Eaton. Reproduced by permission of New Mexico State University Library, Archives and Special Collections.

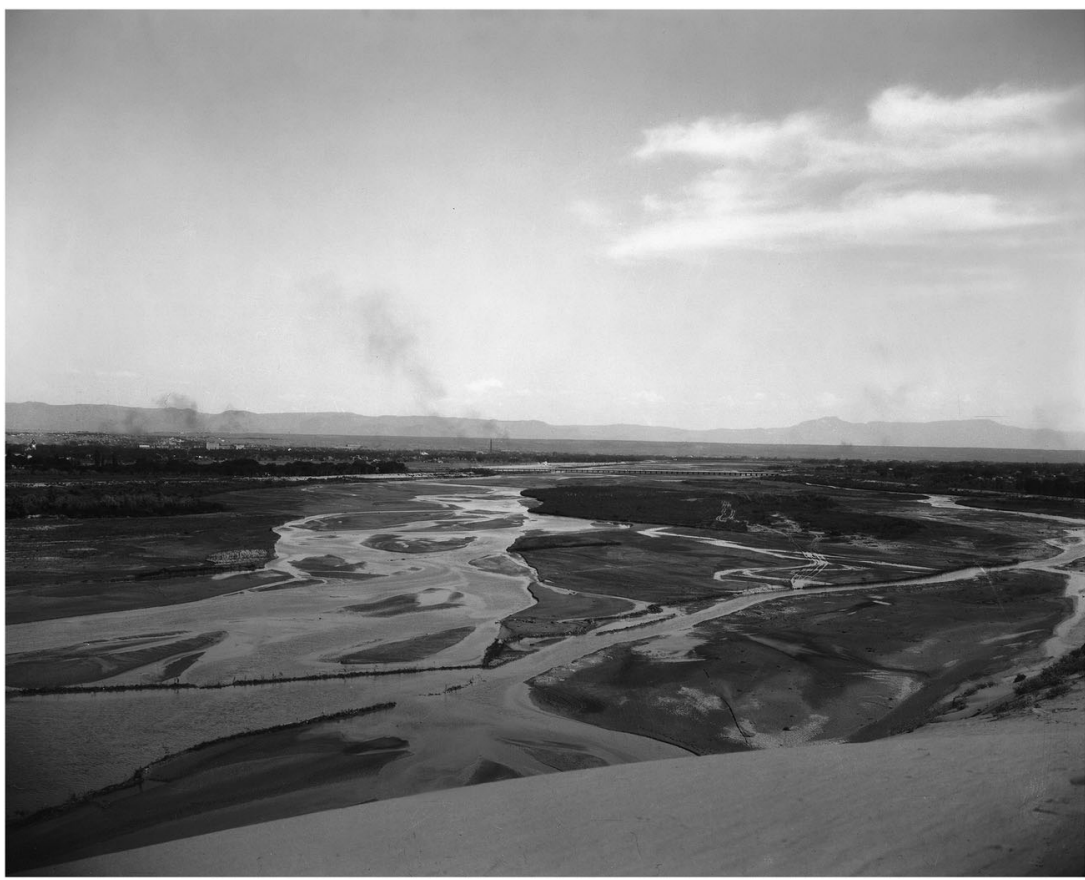

Figure 9. Rio Grande at Central Avenue, Albuquerque, NM, 1933, showing wide, braided channel. Reproduced by permission of the Middle Rio Grande Conservancy District.

spatial variation in sediment and temperature was present in the historical Rio Grande and that RGSM used these habitats. Although documentation of spatial patterns in temperature and sediment in the Rio Grande is limited, historical accounts and studies from less degraded and morphologically intact rivers may suggest how the unconstrained Rio Grande may have functioned. In contrast with the contemporary Rio Grande, rivers with braided channels are complex, heterogeneous systems that change yearly as floods shift fine sediment and new sediment is deposited (Warburton et al., 1993). In addition to differing rates of flow velocity and sediment in adjacent habitats, braided rivers with extensive floodplains can have a diversity of thermal regimes and geomorphology, even across transects perpendicular to the river channel (Mosley, 1983; Junk et al., 1989; Bayley, 1995). In the braided Tagliamento River, Italy, backwaters and pools formed in cutoffs connected to the main and side channels where current velocities of $0.00 \mathrm{~m} \mathrm{~s}^{-1}$ have been measured, indicating stationary water (Arscott et al., 2001). The 


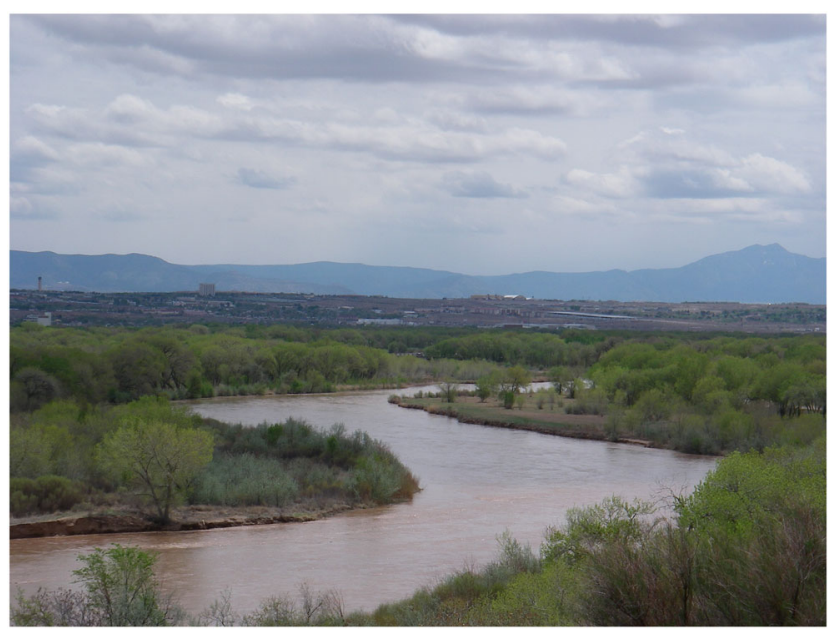

Figure 10. Contemporary view of Rio Grande at Central Avenue, Albuquerque, NM, 2010, 77 years after Figure 9, showing the narrowing and stabilization of the river channel following extensive river training and the closure of Cochiti Reservoir (1975). Reproduced by permission of Dagmar Llewellyn.

observation of reduced flow velocity and stationary water in backwaters and pools adjacent to the main channel is explained by hydrodynamics (Nicholas and McLelland, 1999; Sutton et al., 2004). For example, a combination of field monitoring and simulation of flow velocities in the River Culm, UK, showed how flow dynamics in backwater pools of cutoffs from former channels resulted in high rates of sediment deposition during overbank flooding (Nicholas and McLelland, 1999). We expect that the same processes shown to retain sediment would also retain RGSM eggs, especially if RGSM spawn in these habitats with stationary water.
Historically in the Rio Grande, high flows also produced backwater habitat within the main channel, inundated the floodplain, and filled wetlands, oxbow lakes, and sloughs in former channels (Lee, 1907). For example, a USGS map of the Socorro reach in 1906 shows a braided river with side channels, a floodplain lake, and a cutoff or slough from a former channel (Figure 7). Further onto floodplains, water clarity increases and suspended sediment concentration is reduced as sediments settle (Gourley, 2001; Malard et al., 2006). Water temperatures are often considerably higher beyond the main channel as residency time increases (Mosley, 1983; Tockner et al., 2000; Arscott et al., 2001; Gourley, 2001).

Adult RGSM used these low-velocity habitats prior to major modification of the river channel (Shirey et al., 2008). Minnows collected in August 1874 in pools adjoining the Rio Grande at San Ildefonso, NM (Cope and Yarrow, 1875) had a dominance of nutrient-loving epipelic diatom species, other algae, and detritus in their gut contents. The presence of diatoms indicated the minnows foraged over a mud substrate consistent with a braided channel or lateral flooding and little $\left(<0.2 \mathrm{~m} \mathrm{~s}^{-1}\right)$ to no flow velocity (Cowley et al., 2006; Shirey et al., 2008). Habitats with these features include sloughs, side channels, and backwaters, which are consistent with habitats used by other Hybognathus (Raney, 1939; Copes, 1975; Goldowitz and Whiles, 1999; Scheurer et al., 2003). These laterally flooded habitats were gradually lost from the Rio Grande as a result of increasing flow regulation (Scurlock, 1998; Cowley, 2006; Dean and Schmidt, 2011); for example, riparian wetlands of the middle Rio Grande were reduced by 93\% from 1918 to 1993 (21 052-1498 ha; Crawford et al., 1993).

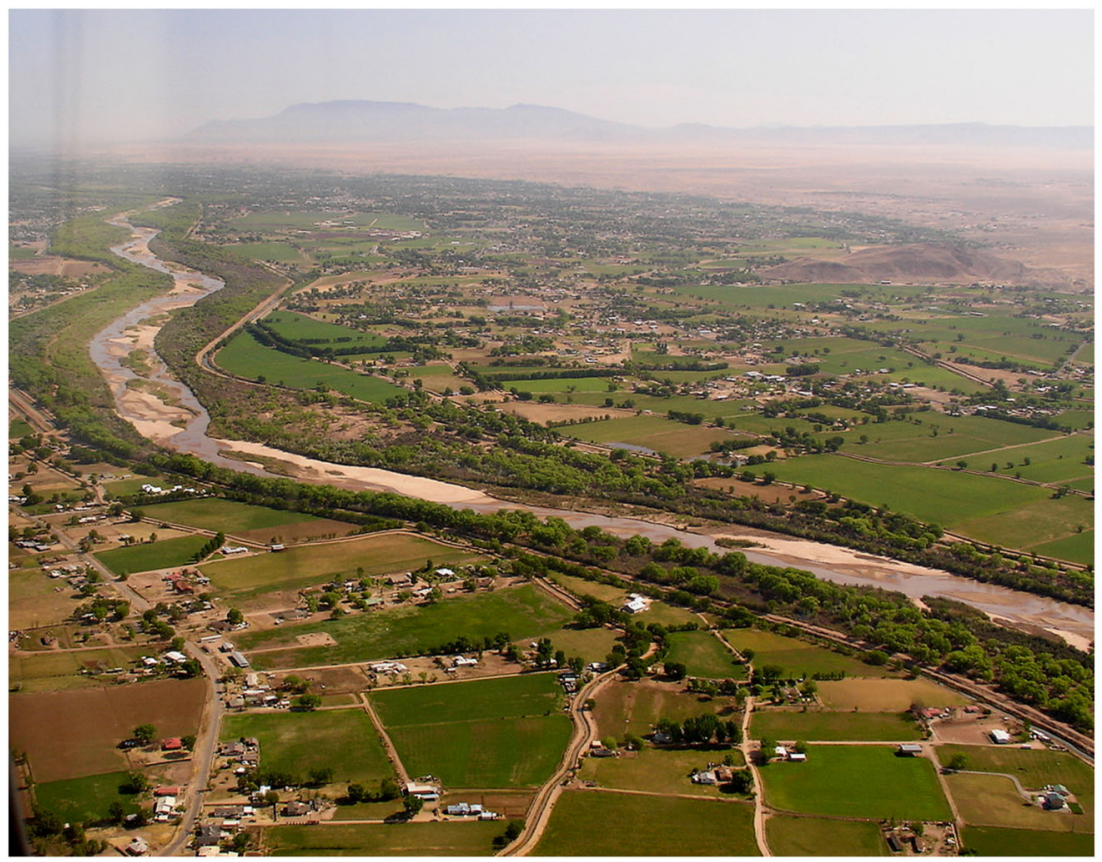

Figure 11. Aerial photograph of Rio Grande Valley looking north towards Isleta and Albuquerque, from near Tome, NM, May 2011, showing the extent of historic floodplain and the contemporary Rio Grande channel, now channelized and straightened and constrained by jetty jacks and levees. Reproduced by permission of Dagmar Llewellyn. 


\section{MAGNITUDE OF DOWNSTREAM EGG DRIFT}

The relative scarcity of floodplain and low-velocity habitats in the contemporary Rio Grande greatly reduces the opportunities for egg retention. Consequently, eggs and newly hatched larvae may drift considerable distances downstream before being entrained (Dudley and Platania, 2007; Widmer et al., 2012). BSM eggs have also been observed drifting in the main channel during summer floods and reservoir releases in the Pecos, Canadian, and Cimarron Rivers (Moore, 1944; Bottrell et al., 1964; Hatch et al., 1985; Lehtinen and Layzer, 1988; Taylor and Miller, 1990; Johnston and Page, 1992). No direct observations of broadcast spawning have been made in situ in these river systems (Moore, 1944; Bottrell et al., 1964). Studies using artificial eggs released in the river channel have shown that highly modified river reaches in the Rio Grande and Pecos River can transport BSM eggs great distances downstream $(<30$ to $>150 \mathrm{~km}$ ) (Dudley and Platania, 2007; Medley et al., 2007, 2009; Widmer et al., 2012). The magnitude of egg displacement is highly variable, dependent upon the complex interaction between discharge, channel dimensions, channel complexity, flow attenuation, channel storage, and river floodplain connectivity, but egg retention may be very efficient when coincident with ascending high flows and floodplain inundation. High rates of downstream egg drift and displacement observed in the contemporary Rio Grande are hypothesized to be a consequence of RGSM spawning in river reaches with severe habitat degradation that has created a 'gun-barrel' that 'shoots' eggs downstream, particularly in years when moderate to high flows are restricted to the main channel with few low-velocity habitats and little floodplain connectivity (Medley et al., 2007; Medley, 2009; Widmer et al., 2012).

\section{EVIDENCE FOR FLOODPLAIN SPAWNING AND USE}

Although we lack historical information on the use of backwater and floodplain habitats by RGSM larvae, in the contemporary Rio Grande, remaining floodplain habitats are used by larval fish and may provide more favourable conditions than the main channel (Pease et al., 2006; Magana, 2012). Recent studies have demonstrated that RGSM may preferentially spawn in backwaters and floodplain habitats when available (Fluder et al., 2007; SWCA Environmental Consulting, 2008, 2009, 2010, 2010, 2011; Gonzales et al., 2012). In May 2008, over 23000 RGSM were captured using hoop nets set in natural and constructed shallow, low-velocity floodplain habitats, during a 3-week period coincident with spring runoff (SWCA Environmental Consulting, 2008, 2009). Many of these fish were gravid or showed signs of recent spawning, often expressing eggs when handled. Fluder et al. (2007) collected RGSM eggs primarily in inlets, inundated shelf habitats, and side channels in shallow habitats with dense grasses and sedges close to fish capture locations. Recent captures of gravid and spent RGSM entering seasonally flooded sites connected to the main channel during high flow years add credence to the minnow being a floodplain spawning fish (Table I) (SWCA Environmental Consulting, 2009, 2010, 2010, 2011; Gonzales et al., 2012).

On the basis of these observations, we suggest that RGSM enter and spawn in floodplain habitats with lowvelocity flows or stationary water where eggs quickly settle after spawning, greatly enhancing egg retention rates. Broadcast spawning is successful in large lowland rivers as demonstrated by the historic distributions and life histories of the other Hybognathus species, five of which are found in small streams to large rivers within the Mississippi River drainage. For example, unpublished surveys of Missouri River habitat found Hybognathus larvae in floodplain scour pools that are continuously connected to the main channel, suggesting adults spawned in these environments (Galat et al., 2004; Whitledge et al., 2005). The reproductive strategy of broadcast spawning in floodplain habitat is also consistent with observations and original descriptions of other Hybognathus species observed spawning in pools and coves continuously connected to the main channel (Table II; Raney, 1939).

\section{EVIDENCE OF AN UPSTREAM POPULATION MOVEMENT OR MIGRATION}

Cross (1950) first provided anecdotal information suggesting the existence of a putative, short-distance spawning migration for BSM to explain observed changes in the abundance of plains minnows (Hybognathus placitus) in a tributary of the Cimarron River, Oklahoma. Two studies have attempted to directly document movement of BSM

Table I. Numbers of RGSM and RGSM eggs captured at habitat restoration sites in the Middle Rio Grande during spring monitoring (SWCA Environmental Consulting, 2009, 2010, 2010, 2011).

\begin{tabular}{|c|c|c|c|c|c|}
\hline Year & $\begin{array}{c}\text { Peak discharge } \\
\text { in } \text { May }^{\mathrm{a}}\end{array}$ & $\begin{array}{l}\text { RGSM captured in habitat } \\
\text { restoration sites on floodplain }\end{array}$ & $\begin{array}{l}\text { Relative percentage of } \\
\text { fish community }\end{array}$ & $\begin{array}{l}\text { RGSM eggs captured } \\
\text { in floodplain habitat }\end{array}$ & $\begin{array}{l}\text { RGSM eggs captured } \\
\text { in main channel }\end{array}$ \\
\hline 2008 & 5150 & 2180 & $61 \cdot 8$ & 340 & 38 \\
\hline 2009 & 4940 & 2057 & 81 & 23 & 85 \\
\hline 2010 & 4900 & 403 & 56 & 112 & 300 \\
\hline 2011 & $919^{b}$ & 39 & $5 \cdot 8$ & 0 & $6548^{c}$ \\
\hline
\end{tabular}

RGSM, Rio Grande silvery minnow.

a At USGS Gage 08330000: Rio Grande at Albuquerque, NM.

${ }^{\mathrm{b}}$ Almost all flow restricted to main channel and little floodplain inundation.

${ }^{\mathrm{c}}$ Includes 3269 eggs caught in habitat restoration sites on margin of main channel due to lack of inundated floodplain habitat at low flows. 
Table II. Habitat requirements and spawning ecology of seven species of Hybognathus.

$\begin{array}{ll}\text { Species Spawning ecology } & \text { Splo }\end{array}$

Hybognathus amarus (Rio Grande silvery minnow)

Hybognathus hankinsoni (brassy minnow)

Hybognathus placitus (plains minnow)

Hybognathus regius (eastern silvery minnow)

Hybognathus argyritis (western silvery);

Hybognathus hayi (cypress minnow);

Hybognathus nuchalis (Mississippi silvery minnow)
Spawn semi-buoyant, non-adhesive eggs in aquaria; eggs sank in aquaria if current not maintained (Platania and Altenbach, 1998; Cowley et al., 2009)

Collected primarily from inlets and pools with little or no flow in the Des Moines River, Iowa; also collected from vegetated, sand-silt bottom pools in streams; adults spawn around peak flow (Starrett 1950; Starrett, 1951)

Spawning took place in beds of vegetation in flooded lateral depressions, marshes, and ponds along a creek; eggs slightly adhesive to vegetation over a mud bottom (Copes, 1975)

Adult brassy minnows moved to intermittent sloughs in the spring to spawn where young of year hatched and emigrated prior to summer drying; adults were observed in schools in permanent sloughs, but no reproduction was observed in permanent sloughs (Goldowitz and Whiles, 1999)

Shallow and deep, large, vegetated backwater habitats; eggs adhesive to vegetation (Falke et al. 2010a,b)

Spawn semi-buoyant eggs during high water in the Cimarron River; egg maturity correlated with increasing temperature; no direct spawning observed (Lehtinen and Layzer, 1988)

Aggregated adults along sandbars and backwaters during receding flows; turbid water prevented observation of spawning (Taylor and Miller, 1990)

Spawning occurs in shallow $(<0.3 \mathrm{~m})$, quiet areas of backwater coves or lagoons near newly sprouted grass; non-adhesive, demersal eggs are scattered over debris on bottom of cove (Raney, 1939)

Unknown, but adults and larvae have been collected in backwater habitats

Girard (1856) collected Hybognathus amarus in a lagoon near Ft. Brown.

(Platania et al., 2003; Archdeacon and Remshardt, 2012) in the Rio Grande. Platania et al. released $\sim 12000$ RGSM marked with visual implant elastomer tags. Sixty-six (66) recaptured fish showed that individual fish move long distances (ranging from $25.17 \mathrm{~km}$ upstream to $15.14 \mathrm{~km}$ downstream). However, net fish movement was $\sim 257 \mathrm{~m}$ downstream. Similarly, Archdeacon and Remshardt (2012) released 6557 PIT-tagged RGSM and documented movement through a rock channel fishway to bypass a water diversion structure. Although both studies confirmed that small numbers of RGSM can swim long distances (Bestgen et al., 2010) and that a few RGSM may move upstream, both studies showed that RGSM also move downstream at a similar or greater magnitude, resulting in little net movement of the population. Neither study provided any evidence for a directed upstream population movement sufficient to overcome the observed and predicted egg displacement $(30-150 \mathrm{~km})$ in the contemporary Rio Grande (Dudley and Platania, 2007; Medley et al., 2007).

Reports summarizing two other unpublished datasets the long-term RGSM population monitoring program data (Dudley and Platania, 2011) and the monitoring of visual implant elastomer-marked RGSM released to augment the wild RGSM population (Remshardt, 2008) - fail to document any evidence to support a hypothesized annual RGSM migration. Hoagstrom et al. (2008), in an analysis of long-term fish community monitoring data from the Pecos River, NM, also failed to provide any evidence of upstream migration of BSM, although migration has been presumed to occur. In summary, since Cross's initial presumption was published, we are unaware of any data or report, either peer-reviewed, published, unpublished, quantitative, or qualitative, that documents a populationscale, upstream movement or migration of the RGSM or any other BSM. Published papers supporting the theory offer only anecdotal or indirect evidence of migration and cite the growing number of previously published papers and unpublished theses and dissertations that rely on the original observations of Moore (1944) and the unconfirmed presumptions of Cross (1950) and others, to argue that longdistance upstream migration to overcome the observed magnitude of downstream egg displacement must be a fundamental aspect of these fishes' reproductive ecology (Platania and Altenbach, 1998; Luttrell et al., 1999; Bonner, 2000; Durham, 2000; Dudley and Platania, 2007; Hoagstrom et al., 2008; Perkin and Gido, 2011).

\section{REINTERPRETATION OF RGSM REPRODUCTIVE ECOLOGY}

Silvery minnows have been reported to be open-water, pelagic broadcast-spawning, non-guarding fish (sensu Balon, 1985), with semi-buoyant eggs that remain suspended to 
drift in turbulent flows (Platania and Altenbach, 1998). Such observations have led to the conclusion that the RGSM is a true pelagic spawning minnow and that eggs drift in the water column as a general strategy to avoid sedimentation and allow long distance, downstream dispersal (Platania, 1995; Platania and Altenbach, 1998; Bestgen et al., 2010). However, (1) the energetic utility of such a strategy for a small bodied fish has been questioned (Medley et al., 2007; Medley, 2009; Widmer et al., 2012), (2) the eggs lack oil globules or air vacuoles to aid drift (Figure 2), (3) the individual benefits and tradeoffs of such dispersal remain undefined and have not been quantified (PBS\&J, 2011, report), and (4) recent monitoring suggests RGSM species enter available floodplain habitats to spawn during the rising limb of the spring snowmelt hydrograph (Gonzales et al., 2012).

Consequently, others have proposed that silvery minnows evolved a life history strategy that promotes egg retention and minimizes downstream population displacement and the need for upstream migrations (Raney, 1939; Medley et al., 2007; Medley, 2009; Widmer et al., 2012). Spawning in warm, seasonally flooded habitats with low flow, lowsediment concentrations, and high bed roughness (submerged vegetation) would allow newly expelled eggs to settle to the bed almost immediately where they would be efficiently retained. These warm habitats would allow eggs to hatch quickly, further reducing the potential for downstream egg displacement (Porter and Massong, 2006) and placing larvae and young of the year fish near excellent rearing habitat (Pease et al., 2006). Here, abundant food resources during floodplain inundation promote high growth rates, high juvenile survival, and greater recruitment into the adult population. The reported positive correlation $\left(r^{2}=0 \cdot 85, p=<0 \cdot 0001\right)$ between the magnitude of the total May and June flow at Albuquerque (Rio Grande at Albuquerque, USGS Gage 08330000) and October RGSM catch rates suggests that floodplain inundation during high flows is an important factor enhancing egg retention and promoting young of the year survival (Miller et al., 2008). Furthermore, fast, turbulent main channel flows are known to have severe negative impacts on drifting larval fish (Harvey, 1987).

Earlier reports of Hybognathus spawning ecology in situ suggested that they were demersal spawners, spawning over inundated floodplain vegetation in habitats connected to the main channel (Raney, 1939; Copes, 1975). More recent reports conclude that RGSM are pelagic spawners (Platania and Altenbach, 1998), although this was based on laboratory observations of spawning and eggs in aerated aquaria that made assumptions about spawning behaviour in the river environment. However, both conclusions may be relevant which suggests a complimentary interpretation of the observations. The ability of newly expelled eggs to settle quickly (Platania and Altenbach, 1998; Cowley et al., 2009) suggests that RGSM are primarily demersal spawners: species that ascend off the bottom to release eggs that subsequently scatter and sink to the bottom. Demersal spawning is consistent with our egg settling calculations, the lack of specific evolutionary adaptations that ensure eggs remain afloat, the original description of the fish, with laboratory observations of spawning (Platania and Altenbach, 1998; Cowley et al., 2009), with in situ observation of spawning habits of other Hybognathus species (Raney, 1939; Copes, 1975), with locations of Hybognathus larvae in floodplain habitats (Goldowitz and Whiles, 1999; Galat et al., 2004; Whitledge et al., 2005; Pease et al., 2006), and with recent observations in the Rio Grande that shows minnows use inundated floodplain habitats (Fluder et al., 2007; Gonzales et al., 2012). The high incidence of eggs reported in inundated floodplain vegetation in high flow years (Table I) also suggests that the species is an open substrate, nonguarding, phytophil, preferring to spawn over floodplain vegetation when available. Floodplain broadcast spawning is also consistent with historical accounts of available habitat in the Rio Grande floodplain (Crawford et al., 1993; Scurlock, 1998; Dean and Schmidt, 2011). Even though the RGSM lives in seasonally high-sediment environments, the species is still a member of a group of closely related BSM that has an ancestral commitment to demersal spawning (i.e. Hybognathus).

We propose that floodplain spawning and ontogenic changes in egg density likely evolved as an evolutionary stable strategy to promote egg retention and preferential settling in seasonally flooded warm, slow-moving, productive environments away from the relatively harsh conditions of the main channel and to prevent egg suffocation subsequent to egg settling. We suggest that change in egg density is a derived trait and the final density of waterhardened eggs is likely an evolutionary tradeoff between the reproductive benefits of egg settling and the costs of sediment-induced egg mortality

The available ecological information suggests that the current description of the reproductive life history of the RGSM be refined. Rather than an obligate main channel, pelagic spawning fish whose eggs drift long distances downstream, requiring a subsequent longitudinal upstream migration or long-distance dispersal of individuals, the available life history evidence suggests RGSM adults move laterally from the main channel to the floodplain to spawn in inundated floodplain vegetation or areas with little to no flow velocity (Fluder et al., 2007; SWCA Environmental Consulting, 2008, 2009, 2010, 2010, 2011). The evidence supports the conclusions of prior studies suggesting that spawning strategies and egg density of BSM evolved in response to a suite of selective pressures to maximize egg retention reduce the risks of sediment suffocation, promote young of year survival, and minimize downstream displacement of populations (Medley et al., 2007; Medley, 2009; Widmer et al., 2012). We suggest that the hydrodynamic mechanisms that promote egg retention and survival described in this paper may be generally applicable to other small bodied, broadcast-spawning fish species with drifting egg and larval stages living in large floodplain rivers.

To date, the evidence fails to support the presumption that upstream migration is a fundamental aspect of RGSM life history and BSM reproductive ecology. However, if 
upstream migration were confirmed, our hypothesis would not be invalidated. In the absence of a documented evolutionary benefit to long downstream dispersal, adaptive behaviours that employ passive mechanisms to reduce egg drift are energetically advantageous and will likely exist, even if some level of upstream migration is required to overcome an unavoidable level of downstream displacement (Speirs and Gurney, 2001).

\section{CONSERVATION AND MANAGEMENT}

Effective conservation and recovery of RGSM and other BSM populations requires an understanding of limiting factors. The difficulty identifying specific cause and effect relationships between the changes in fish communities and the environmental drivers that cause population declines is due to the multiple factors that might influence minnow populations, the complex management history, and the lack of high quality historic data.

Our review suggests that river fragmentation may not be the primary cause of the demise of the RGSM and other BSM (Dudley and Platania, 2007; Perkin and Gido, 2011). Rather, fragmentation is likely a general indicator, correlated to BSM extirpation that reflects the number of dams and the magnitude of numerous attendant geomorphic, hydrologic, and ecological impacts associated with their construction and use (Ligon et al., 1995). Water resource management changes the magnitude, frequency, duration, timing, variability, and rate of change of flows and often greatly reduces the total amount of water in the river, reducing the magnitude of large flows and increasing the frequency of low flows and river drying. Reservoir impoundment traps sediment and alters downstream thermal regimes (Robinson et al., 1998) and water quality. Changes in the relative balance of water and sediment fundamentally alter the natural geomorphology of these rivers (Lane, 1955). Sediment-starved river channels narrow, incise, and disconnect from their historic floodplains with a subsequent loss of habitat complexity and availability (Dean and Schmidt, 2011). These changes are promoted through tributary sediment control, river straightening and channelization, levee construction and river training using jetty jacks and non-native vegetation to improve flood control, increase channel stability and limit water conveyance losses (Scurlock, 1998; Cowley, 2006). These geomorphic changes altered the abundance and availability of both river channel and floodplain habitats and eliminated or changed the timing and magnitude of seasonal life history cues important for the reproductive ecology of these native fishes.

The physical effects of water resource development were greatly exacerbated by secondary biological management actions (Rinne and Miller, 2006). Native fish were poisoned to promote the establishment of non-native sport fisheries in the newly created cold-water habitats below hypolimnetic dam releases (U. S. Bureau of Sport Fisheries and Wildlife, 1962; Hubbs, 1963; Schmidt et al., 1998). Predatory sport fish were stocked in both the dam outlet and the reservoir impoundments where predation further impacted native fish.
Additionally, the release of live bait has led to the establishment of closely related, non-native minnow species that have caused the extirpation and decrease of native minnow populations through competition and hybridization (Hoagstrom et al., 2010).

Removal of dams and irrigation diversions and the construction of fish passage have been proposed as the primary conservation and recovery strategy to address fragmentation (Dudley and Platania, 2007; Perkin and Gido, 2011). However, although longitudinal connectivity is a long-term genetics concern (Alò and Turner, 2005), in the absence of any data to indicate upstream fish migration there is little reason to believe that removal of irrigation diversion dams will be effective without improving habitat features that retain eggs and reduce drift (Speirs and Gurney, 2001). Authors of a recent independent evaluation of the feasibility of fish passage for RGSM at San Acacia Diversion Dam on the Rio Grande concluded that there is no evidence to suggest that RGSM migrate or that the provision of fish passage to re-establish longitudinal connectivity will benefit RGSM (PBS\&J, 2011). They concluded that habitat restoration within reaches should be the highest priority. Additionally, removal of large mainstem dams and irrigation diversions is not a short-term feasible goal for managing endangered species, especially in the absence of evidence to support these actions.

Evidence supporting floodplain spawning coincident with rapidly increasing flows, and short egg drift distances in wide, geomorphically complex river reaches with connected floodplains (Medley et al., 2007; Gonzales et al., 2012; Widmer et al., 2012), suggests that restoration actions that promote historic channel geomorphology and river-floodplain connectivity in short river reaches is the near-term conservation need for demersal spawning BSM (Medley, 2009; PBS\&J, 2011; Magana, 2012). Floodplain restoration will become more important in the future as vertical accretion of sediments during overbank flooding continues to reduce the areal extent of functional floodplain accessible to spawning fish. Management actions that restore the important natural attributes of the historic flow regime, remove bank stabilization structures such as jetty jacks, promote bank erosion and lateral migration of river channels, and create low-velocity main channel and floodplain habitat (pools, sloughs, and side channels) are likely to be beneficial (Gore and Shields, 1995; Sparks, 1995; MRGESACP (Middle Rio Grande Endangered Species Act Collaborative Program), 2004; Medley et al., 2007; Medley, 2009; Widmer et al., 2012).

In riverine environments where water use for habitat protection needs must be balanced by the increasing demand for other consumptive uses (agricultural, residential, and industrial), recovery activities must be based on science and clear understanding of cause and effect relationships. Although scientific uncertainty may remain, decisions must be made on the most parsimonious interpretation of the available evidence (Galat and Zweimüller, 2001). As once common species such as the RGSM become imperilled, scientists and river managers 
must place life history research in the context of historical conditions to understand the appropriate mechanisms to recover fish populations and restore fish habitat.

\section{ACKNOWLEDGEMENTS}

Patrick Shirey was supported by a fellowship from the NSF IGERT grant award \#0504495 to the GLOBES graduate training programme at the University of Notre Dame, with additional funding from the UND Center for Aquatic Conservation, a UND CEST Bayer Predoctoral Research Fellowship, and the George Melendez Wright Climate Change Fellowship from the NPS. We thank Mike Harvey, Will Clements, John Wullschleger, Gavin Medley, and an anonymous reviewer for their comments on previous versions of this manuscript and the many people whose discussions helped improve this manuscript.

\section{REFERENCES}

Alò D, Turner TF. 2005. Effects of habitat fragmentation on effective population size in the endangered Rio Grande silvery minnow. Conservation Biology 19(4): 1138-1148. DOI: 10.1111/j.15231739.2005.00081.x.

Archdeacon TP, Remshardt WJ. 2012. Observations of hatchery-reared Rio Grande silvery minnow using a fishway. North American Journal of Fisheries Management 32: 648-655. DOI: 10.1080/ 02755947.2012 .681013

Arscott DB, Tockner K, Ward JV. 2001. Thermal heterogeneity along a braided floodplain river (Tagliamento River, Northeastern Italy). Canadian Journal of Fisheries and Aquatic Sciences 58: 2359-2373. DOI: $10.1139 /$ cjfas-58-12-2359.

Balon EK (ed.). 1985. Early life histories of fishes: new developmental, ecological, and evolutionary perspectives. Developments in Environmental Biology of Fishes 5. Kluwer Academic Publishers: Dordrecht.

Bayley PB. 1995. Understanding large river-floodplain ecosystems. Bioscience 45(3): 153-158. DOI: $10.2307 / 1312554$

Benke AC. 1990. A perspective on America's vanishing streams. Journal of the North American Benthological Society 9: 77-88. DOI: 10.2307/ 1467936.

Bestgen KR, Platania SP. 1991. Status and conservation of the Rio Grande silvery minnow, Hybognathus amarus. The Southwestern Naturalist 36: 225-232. DOI: $10.2307 / 3671925$.

Bestgen KR, Mefford B, Bundy JM, Walford CD, Compton RI. 2010. Swimming performance and fishway model passage success of Rio Grande silvery minnow. Transactions of the American Fisheries Society 139: 433-448. DOI: 10.1577/T09-085.1.

Bonner TH. 2000. Life history and reproductive ecology of the Arkansas River shiner and peppered chub in the Canadian River, Texas and New Mexico. Doctoral Dissertation, Texas Tech University, Lubbock.

Bottrell CE, Ingersol RH, Jones RW. 1964. Notes on the embryology, early development, and behavior of Hybopsis aestivalis tetranemus (Gilbert). Transactions of the American Microscopy Society 83: 391-399. DOI: $10.2307 / 3224757$

Cheng NS. 2009. Comparison of formulas for drag coefficient and settling velocity of spherical particles. Powder Technology 189(3): 395-398. DOI: 10.1016/j.powtec.2008.07.006

Collier M, Webb RH, Schmidt JC. 1996. Dams and rivers: a primer on the downstream effects of dams. United States Geological Survey, Circular 1126.

Cope ED, Yarrow HC. 1875. Report upon the collections of fishes made in portions of Nevada, Utah, California, Colorado, New Mexico, and Arizona during the years 1871-1874, pp. 635-703. In United States Army Engineers Department Report, in charge of George M. Wheeler, Geographer and Geologist of the Exploration and Surveys west of the 100th Meridian, 5, Chapter 6.

Copes FA. 1975. Ecology of the brassy minnow, Hybognathus hankinsoni (Cyprinidae). Reports on the fauna and flora of Wisconsin, Part III.
Report 10:46-72. Museum of Natural History, University of Stevens Point, Stevens Point, Wisconsin.

Cowley DE. 2006. Strategies for ecological restoration of the middle Rio Grande in New Mexico and recovery of the endangered Rio Grande silvery minnow. Reviews in Fisheries Science 14: 169-186. DOI 10.1080/10641260500341619.

Cowley DE, Alleman J, McShane RR, Shirey PD. 2005. Effects of salinity and suspended sediment on physical properties of the egg of the Rio Grande silvery minnow (Hybognathus amarus). Water Resources Research Institute Technical Completion Report 334. http://wrri.nmsu. edu/publish/techrpt/abstracts/abs334.html

Cowley DE, Shirey PD, Hatch MD. 2006. Ecology of the Rio Grande silvery minnow (Cyprinidae: Hybognathus amarus) inferred from specimens collected in 1874. Reviews in Fisheries Science 14(1-2): 111-125. DOI: 10.1080/10641260500341494.

Cowley DE, Alleman JC, Sallenave R, McShane RR, Shirey PD. 2009. Effects of salinity on specific gravity and viability of eggs of a North American minnow (Cyprinidae). Scientia Marina 73(S1): 47-58. DOI: 10.3989/scimar.2009.73s1047.

Crawford CS, Culley AS, Leutheuser R, Sifuentes MS, White LH, Wilber JP. 1993. Middle Rio Grande ecosystem: bosque biological management plan. U.S. Fish and Wildlife Service, District 2 , Albuquerque, New Mexico, $291 \mathrm{pp}$.

Cross FB. 1950. Effects of sewage and of a headwaters impoundment on the fishes of Stillwater Creek in Payne County, Oklahoma. American Midland Naturalist 43(1): 128-145. DOI: 10.2307/2421883.

Deacon JE, Kobetich G, Williams JD, Contreras S. 1979. Fishes of North America endangered, threatened, or of special concern. Fisheries 4: $29-44$.

Dean DJ, Schmidt JC. 2011. The role of feedback mechanisms in historic channel changes of the lower Rio Grande in the Big Bend region. Geomorphology 126: 333-349. DOI: 10.1016/j.geomorph.2010.03.009.

Dudley RK, Platania SP. 2007. Flow regulation and fragmentation imperil pelagic spawning riverine fishes. Ecological Applications 17: 2074-2086. DOI: $10.1890 / 06-1252.1$.

Dudley RK, Platania SP. 2011. Rio Grande silvery minnow population monitoring program results from September 2009 to October 2010. American Southwest Ichthyological Researchers, L.L.C.. For Middle Rio Grande Endangered Species Act Collaborative Program, U. S. Bureau of Reclamation, Albuquerque, NM.

Durham BW. 2000. Influence of stream discharge on reproductive success of a prairie stream fish assemblage. Master's Thesis, Texas Tech University, Lubbock.

Edwards RJ, Contreras-Balderas S. 1991. Historical changes in the ichthyofauna of the lower Rio Grande (Rio Bravo del Norte), Texas and Mexico. The Southwestern Naturalist 36: 201-212. DOI: 10.2307/ 3671922 .

Falke JA, Bestgen KR, Fausch KD. 2010. Streamflow Reductions and Habitat Drying Affect Growth, Survival, and Recruitment of Brassy Minnow across a Great Plains Riverscape. Transactions of the American Fisheries Society 139(5): 1566-1583.

Falke JA, Fausch KD, Bestgen KR, Bailey LL. 2010. Spawning phenology and habitat use in a Great Plains, USA, stream fish assemblage: an occupancy estimation approach. Canadian Journal of Fisheries and Aquatic Sciences 67: 1942-1956.

Fluder J, Porter MD, McAlpine B. 2007. Analyzing floodplain and aquatic nursery habitat of the Rio Grande silvery minnow at different hydrologic flows. GIS Spatial Analysis in Fishery and Aquatic Sciences 3: $387-398$

Galat DL, Whitledge GW, Gelwicks, GT. 2004. Influence of lateral connectivity on larval fish assemblange structure and habitat use in lower Missouri River floodplain water bodies. Final Report to Missouri Department of Conservation. U.S. Geological Survey, Missouri Cooperative Fish and Wildlife Research Unit, University of Missouri, Columbia. $114 \mathrm{pp}$

Galat DL, Zweimüller I. 2001. Conserving large-river fishes: is the highway analogy an appropriate paradigm? Journal of the North American Benthological Society 20: 266-279. DOI: 10.2307/1468321.

Girard C. 1856. Researches upon the cyprinoid fishes inhabiting the freshwaters of the United States of America, west of the Mississippi Valley, from specimens in the museum of the Smithsonian Institution. Proceedings of the National Academy of Sciences 8: 165-213.

Goldowitz BS, Whiles MR. 1999. Investigations of fish, amphibians and aquatic invertebrates within the middle Platte River system. U.S Environmental Protection Agency, Report to Platte Watershed Program, University of Nebraska, Lincoln.

Gonzales EJ, Haggerty GM, Lundahl A. 2012. Using fyke net capture data to assess daily trends in abundance of spawning Rio Grande silvery 
minnow. North American Journal of Fisheries Management 32(3): 544-547. DOI: 10.1080/02755947.2012.675949.

Gore JA, Shields FD. 1995. Can large rivers be restored? Bioscience 45(3): 142-152. DOI: $10.2307 / 1312553$.

Gourley JL. 2001. Primary productivity in a large arid-zone river: the Green River, Utah. MSc Thesis, Utah State University, Logan, Utah.

Graf WH. 1971. Hydraulics of Sediment Transport. McGraw-Hill: NewYork.

Harvey BC. 1987. Susceptibility of young-of-the-year fishes to downstream displacement by flooding. Transaction of the American Fisheries Society 116: 851-855. DOI: $10.1577 / 1548-8659(1987) 116<851$ : SOYFTD $>2.0 . \mathrm{CO} ; 2$.

Haslouer SG, Eberle ME, Edds DR, Gido KB, Mammoliti CS, Triplett JR, Collins JT, Distler DA, Huggins DG, Stark WJ. 2005. Current status of native fish species in Kansas. Transactions of the Kansas Academy of Science 108(1/2): 32-46. DOI: 10.1660/0022-8443(2005)108[0032: CSONFS]2.0.CO;2.

Hatch MD, Baltosser WH, Schmitt CG. 1985. Life history and ecology of the bluntnose shiner (Notropis simus pecosensis) in the Pecos River of New Mexico. The Southwestern Naturalist 30(4): 555-562. DOI: $10.2307 / 3671049$.

Hirshfield MF, Tinkle DW. 1975. Natural selection and the evolution of reproductive effort. Proceedings of the National Academy of Sciences 72(6): 2227-2231. DOI: 10.1073/pnas.72.6.2227.

Hoagstrom CW, Brooks JE, Davenport SR. 2008. Spatiotemporal population trends of Notropis simus pecosensis in relation to habitat conditions and the annual flow regime of the Pecos River, 1992-2005. Copeia 1: 5-15. DOI: 10.1643/CE-07-002.

Hoagstrom CW, Zymonas ND, Davenport SR, Propst DL, Brooks JE. 2010. Rapid species replacements between fishes of the North American plains: a case history from the Pecos River. Aquatic Invasions 5(2): 141-153. DOI: 10.3391/ai.2010.5.2.03

Hubbs C. 1963. An evaluation of the use of rotenone as a means of "improving" sports fishing in the Concho River, Texas. Copeia 1: 199-203. DOI: 10.2307/1441320.

Johnston CE, Page LM. 1992. The evolution of complex reproductive strategies in North American minnows (Cyprinidae). In Systematics, Historical Ecology, and North American Freshwater Fishes, RI Mayden (ed). Stanford University Press: Stanford, California, USA; 600-621.

Junk WJ, Bayley PB, Sparks RE. 1989. The flood pulse concept in riverfloodplain systems. In Proceedings of the International Large River Symposium (LARS), Dodge DP (ed). Canadian Special Publication of Fisheries and Aquatic Sciences: Ottawa, Canada; 110-127.

Lagasse PF. 1981. Geomorphic response of the Rio Grande to dam construction. New Mexico Geological Society, Special Publication 10: 27-46.

Lane EW. 1955. The importance of fluvial morphology in hydraulic engineering. American Society of Civil Engineers Proceedings, Hydraulic Division 81(745): 1-17

Lee WT. 1907. Water resources of the Rio Grande Valley in New Mexico. U.S. Geological Survey Water Supply and Irrigation Papers Washington, D.C. 188: 1-59.

Lehtinen SF, Layzer JB. 1988. Reproductive cycle of the plains minnow, Hybognathus placitus (Cyprinidae), in the Cimarron River, Oklahoma. The Southwestern Naturalist 33: 27-33. DOI: 10.2307/3672085.

Ligon FK, Dietrich WE, Trush WJ. 1995. Downstream ecological effects of dams. BioScience 45(3): 183-192. DOI: 10.2307/1312557.

Luttrell GR, Echelle AA, Fisher WL, Eisenhour DJ. 1999. Declining status of two species of the Macrhybopsis aestivalis complex (Teleostei Cyprinidae) in the Arkansas River Basin and related effects of reservoirs as barriers to dispersal. Copeia 1999(4): 981-989. DOI: $10.2307 / 1447973$

Magana HA. 2012. Habitat use of the Rio Grande silvery minnow (Hybognathus amarus) during a long-term flood pulse in the Middle Rio Grande, New Mexico. Environmental Biology of Fishes 92(2): 201-212. DOI: 10.1007/s10641-012-9977-5.

Malard F, Uehlinger U, Zah R, Tockner K. 2006. Flood-pulse and riverscape dynamics in a braided glacial river. Ecology 87: 704-716. DOI: $10.1890 / 04-0889$.

Medley CN, Kehmeier JW, Myers OB, Valdez RA. 2007. Simulated transport and retention of pelagic fish eggs during an irrigation release in the Middle 3 River, New Mexico. Journal of Freshwater Ecology 22: 499-513. DOI: 10.1080/02705060.2007.9664180.

Medley CN, Kehmeier JW, Myers OB, Valdez RA. 2009. Authors response. Journal of Freshwater Ecology 24(4): 680-683. DOI: 10.1080/02705060.2009.9664348

Medley CN. 2009. Habitat restoration and a conservation strategy for the Rio Grande silvery minnow. In Water, Natural Resources, and the
Urban Landscape: The Albuquerque Region, Vol 3. Price LG, Bland D, Johnson PS, Connell SD (eds). New Mexico Bureau of Geology and Mineral Resources (Socorro, NM) 102-107. ISBN: 978-1883905-27-9.

Miller P, Dudley R, Medley CN. 2008. A preliminary template for integrating Rio Grande hydrologic data with Rio Grande silvery minnow demography. Unpublished memo of Silvery Minnow Biology Working Group, Middle Rio Grande Endangered Species Collaborative Program. USBR, Albuquerque, NM.

Miller RR, Williams JD, Williams JE. 1989. Extinctions of North American fishes during the past century. Fisheries 14(6): 22-38. DOI: 10.1577/1548-8446(1989)014<0022:EONAFD $>2.0 . C O ; 2$

Molles MD, Crawford CS, Ellis LM, Vallet HM, Dahm CN. 1998. Managed flooding for riparian ecosystem restoration. BioScience $\mathbf{4 8}$ : 749-756. DOI:10.2307/1313337.

Moore GA. 1944. Notes on the early life history of Notropis girardi. Copeia 4: 209-214. DOI: 10.2307/1438675.

Mosley MP. 1983. Variability of water temperatures in the braided Ashley and Rakaia rivers. New Zealand Journal of Marine and Freshwater Research 17: 331-342. DOI: 10.1080/00288330.1983.9516007.

MRGESACP (Middle Rio Grande Endangered Species Act Collaborative Program). 2004. Habitat restoration plan for the middle Rio Grande. Tetra Tech, Albuquerque, New Mexico.

Mussetter Engineering, Inc. (2002). Geomorphic and sedimentologic investigations of the Middle Rio Grande between Cochiti Dam and Elephant Butte Reservoir. Prepared for New Mexico Interstate Stream Commission. Albuquerque, New Mexico. Mussetter Engineering, Inc., Fort Collins, CO.

Nicolas AP, McLelland SJ. 1999. Hydrodynamics of a floodplain recirculation zone investigated by field monitoring and numerical simulation. In Marriot, S.B. and J. Alexander (eds.). Floodplains: Inerdisciplinary Approaches. Geological Society, London, Special Publications 163: 15-26.

PBS\&J. 2011. Scientific review report: San Acacia fish passage. PBS\&J, Missoula, MT. Prepared for Middle Rio Grande Endangered Species Collaborative Program, U.S. Bureau of Reclamation, Albuquerque, NM.

Pease AA, Davis JJ, Edwards MS, Turner TF. 2006. Habitat and resource use by larval and juvenile fishes in an arid-land river (Rio Grande, New Mexico). Freshwater Biology 51: 475-486. DOI: 10.1111/j.13652427.2005.01506.x.

Perkin JS, Gido KB. 2011. Stream fragmentation thresholds for a reproductive guild of Great Plains fishes. Fisheries 36(8): 371-383. DOI: $10.1080 / 03632415.2011 .597666$.

Platania SP. 1991. Fishes of the Rio Chama and upper Rio Grande, New Mexico, with preliminary comments on their longitudinal distribution. The Southwestern Naturalist 36: 186-193. DOI: $10.2307 / 3671919$.

Platania SP. 1995. Reproductive biology and early life-history of Rio Grande silvery minnow, Hybognathus amarus. Prepared for U.S. Army Corps of Engineers under purchase order DACW47-94-P-0462. Albuquerque, NM.

Platania SP, Altenbach CS. 1998. Reproductive strategies and egg types of seven Rio Grande Basin cyprinids. Copeia 3: 559-569. DOI: 10.2307/ 1447786.

Platania SP, Farrington MA, Brandenburg WH, Gottleib SJ, Dudley RK. 2003. Movement patterns of Rio Grande silvery minnow, Hybognathus amarus, in the San Acacia reach of the Rio Grande during 2002. American Southwest Ichthyological Research Foundation. For U. S. Bureau of Reclamation: P.O. No. 01-PG 40-0187. Unpublished Report.

Platania SP, Dudley RK. 2005. Spawning periodicity of Rio Grande silvery minnow during 2004. Report prepared for the Middle Rio Grande Endangered Species Collaborative Program. U. S. Bureau of Reclamation, Albuquerque Area Office, Albuquerque, New Mexico, USA. Contract No. 03CR408031.

Propst DL. 1999. Threatened and endangered fishes of New Mexico. Technical Report No. 1, New Mexico Game and Fish Department, Santa Fe, NM, USA.

Porter MD, Massong TM. 2004. Analyzing changes in river channel morphology using GIS for Rio Grande silvery minnow habitat assessment. GIS/Spatial Analyses in Fishery and Aquatic Sciences: 433-446.

Porter MD, Massong TM. 2006. Progress report 2005 - contributions to delisting the Rio Grande silvery minnow: egg habitat identification. Report to the Bureau of Reclamation Science and Technology Program, 39 pp.

Raney EC. 1939. The breeding habits of silvery minnow, Hybognathus regius Girard. American Midland Naturalist 21: 674-680. DOI: $10.2307 / 2420524$.

Remshardt WJ. 2008. Rio Grande silvery minnow augmentation in the middle Rio Grande, New Mexico. Annual Report 2007. Submitted to U.S. Bureau of Reclamation, Albuquerque, New Mexico. 55 p. 
Rinne JN, Miller D. 2006. Hydrology, geomorphology and management: implications for sustainability of native southwestern fishes. Reviews in Fisheries Science 14: 91-110.

Robinson AT, Clarkson RW, Forrest RE. 1998. Dispersal of larval fishes in a regulated river tributary. Transactions of the American Fisheries Society 127: 772-786. DOI: 10.1577/1548-8659(1998)127<0772: DOLFIA $>2.0 . \mathrm{CO} ; 2$.

Scheurer JA, Fausch KD, Bestgen KR. 2003. Multiscale processes regulate brassy minnow persistence in a Great Plains River. Transactions of the American Fisheries Society 132: 840-855. DOI: 10.1577/ T02-037.

Scurlock D. 1998. From the Rio to the Sierra: an environmental history of the Middle Rio Grande Basin. General Technical Report RMRS-GTR5. Fort Collins, CO: U.S. Department of Agriculture, Forest Service, Rocky Mountain Research Station. 440 pp.

Schmidt JC, Webb RH, Valdez RA, Marzolf GR, Stevens LE. 1998. Science and values in river restoration in the Grand Canyon. Bioscience 48(9): 735-747. DOI: $10.2307 / 1313336$.

Shirey PD, Cowley DE, Sallenave R. 2008. Diatoms from gut contents of museum specimens of an endangered minnow suggest long-term ecological changes in the Rio Grande (US). Journal of Paleolimnology 40(1): 263-272. DOI: 10.1007/s10933-007-9156-4.

Shirey PD, Lamberti GA. 2010. Assisted colonization under the U.S. Endangered Species Act. Conservation Letters 3: 45-52. DOI: 10.1111/ j.1755-263X.2009.00083.x.

Sparks ER. 1995. Need for ecosystem management of large rivers and their floodplains. BioScience 45(3): 168-182. DOI: 10.2307/ 1312556.

Speirs DC, Gurney WSC. 2001. Population persistence in rivers and estuaries. Ecology 82(5): 1219-1237. DOI: 10.1890/0012-9658(2001) 082[1219:PPIRAE]2.0.CO;2.

Starrett WC. 1950. Food relationships of the minnows of the Des Moines River, Iowa. Ecology 31: 216-233.

Starrett WC. 1951. Some factors affecting the abundance of minnows in the Des Moines River, Iowa. Ecology 32: 13-27.

Sublette JE, Hatch MD, Sublette M. 1990. The Fishes of New Mexico. University of New Mexico Press: Albuquerque, NM, USA. ISBN 0-8263-1179-2.

Sutton RI, Nicholas AP, Walling DE. 2004. Monitoring and modeling flow and suspended sediment transport processes in alluvial cutoffs. Sediment Transfer Through the Fluvial System: Proceedings of the International Symposium Held at Moscow, Russia. IAHS Publication 288: $410-416$.

Swanson BJ, Meyer GA, Coonrod JE. 2011. Historical channel narrowing along the Rio Grande near Albuquerque, New Mexico in response to peak discharge reductions and engineering: magnitude and uncertainty of change from air photo measurements. Earth Surface Processes and Landforms 36: 885-900. DOI: 10.1002/esp.2119.

SWCA Environmental Consulting. 2008. Los Lunas habitat restoration fisheries monitoring. Project Summary Report. U.S. Bureau of Reclamation, Albuquerque, NM.

SWCA Environmental Consulting. 2009. Middle Rio Grande riverine restoration fisheries monitoring spring 2008 final report. Prepared for New Mexico Interstate Stream Commission, Santa Fe, NM.

SWCA Environmental Consulting. 2010a. 2009 Monitoring report for Albuquerque reach riverine restoration and habitat improvement for Rio
Grande silvery minnow. Prepared for New Mexico Interstate Stream Commission, Santa Fe, NM.

SWCA Environmental Consulting. 2010b. Middle Rio Grande riverine restoration fisheries monitoring spring 2010 final report. Prepared for New Mexico Interstate Stream Commission, Santa Fe, NM.

SWCA Environmental Consulting. 2011. Middle Rio Grande riverine restoration fisheries monitoring spring 2011 final report. Prepared for New Mexico Interstate Stream Commission, Santa Fe, NM.

Taylor CM, Miller RJ. 1990. Reproductive ecology and population structure of the plains minnow, Hybognathus placitus (Pisces: Cyprinidae), in central Oklahoma. American Midland Naturalist 123: 32-39. DOI: $10.2307 / 2425757$.

Tockner K, Malard F, Ward JV. 2000. An extension of the flood pulse concept. Hydrological Processes 14: 2861-2883. DOI: 10.1002/10991085(200011/12)14:16/17<2861::AID-HYP124>3.0.CO;2-F.

U. S. Bureau of Sport Fisheries and Wildlife. 1962. Ten years of sport fish restoration. The Dingell Johnson Program. Washington, D. C., U. S. Bureau of Sport Fisheries and Wildlife.

U.S. Fish and Wildlife Service. 2008. Endangered and threatened wildlife and plants; establishment of a nonessential experimental population of Rio Grande silvery minnow in the Big Bend reach of the Rio Grande in Texas. Federal Register 73(236): 74357-74372.

Warburton JT, Davies RH, Mandl MG. 1993. A meso-scale field investigation of channel change and floodplain characteristics in an upland braided gravel-bed river, New Zealand. In: Best, J.L and C.S. Bristow (eds). Braided Rivers, Geological Society Special Publication 75: 241-255. DOI: 10.1144/GSL.SP.1993.075.01.15.

Ward FA, Booker JF. 2003. Economic costs and benefits of instream flow protection for endangered species in an international basin. Journal of the American Water Resources Association 39: 427-440. DOI: 10.1111/ j.1752-1688.2003.tb04396.x.

Ward FA, Booker JF. 2006. Economic impacts of instream flow protection for the Rio Grande silvery minnow in the Rio Grande basin. Reviews in Fisheries Science 14: 1-16. DOI: 10.1080/10641260500341734.

Ward FA, Pulido-Velázquez M. 2008. Efficiency, equity, and sustainability in a water quantity-quality optimization model in the Rio Grande basin. Ecological Economics 66: 23-37. DOI: 10.1016/j.ecolecon. 2007.08.018.

Ward JV, Stanford JA. 1995. Ecological connectivity in alluvial river ecosystems and its disruption by flow regulation. Regulated Rivers: Research \& Management 11: 105-119. DOI: 10.1002/rrr.3450110109.

Whitledge GW, Galat DL, Gelwicks GT. 2005. Habitat use by fishes in periodically and continuously connected lower Missouri River floodplain water bodies. Final Report to Missouri Department of Conservation.

Widmer AM, Fluder JJ, Kehmeier JW, Medley CN, Valdez RA. 2012. Drift and retention of pelagic spawning minnow eggs in a regulated river. River Research and Applications 28: 192-203. DOI: 10.1002/ rra.1454.

Williams JE, Johnson JE, Hendrickson DA, Contreras-Balderas S, Williams JD, Navarro-Mendoza M, McAllister DE, Deacon JE. 1989. Fishes of North America endangered, threatened, or of special concern. Fisheries 14(6): 2-20. DOI: 10.1577/1548-8446(1989)014<0002: FONAET $>2.0 . \mathrm{CO} ; 2$.

Woo HS, Julien PY, Richardson EV. 1988. Suspension of large concentrations of sands. Journal of Hydraulic Engineering 114(8): 888-898. DOI: 10.1061/(ASCE)0733-9429(1988)114:8(888). 